\title{
Effect of Brick Forming Load on Mechanical Properties of Fly-Ash Bricks
}

\author{
Md. Ashikuzzaman*, Tarif Uddin Ahmed, Zahidul Alam and Md. Altaf Hossain \\ Department of Civil Engineering, Rajshshai University of Engineering \& Technology (RUET), Bangladesh
}

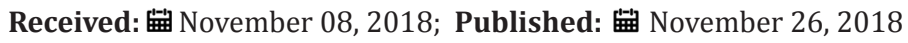

*Corresponding author: Md. Ashikuzzaman, M. Sc. Student, Department of Civil Engineering, Rajshahi University of Engineering \& technology (RUET), Rajshahi-6204, Bangladesh

\begin{abstract}
Manufacturing of fly-ash bricks are the very useful alternatives of conventional burnt clay bricks. Manufacturing of clay bricks cause top soil removal, environmental pollution and health problems. To avoid all this environmental threats an attempt is made to manufacture of bricks using fly-ash, gypsum, sand and cement. Mainly fly-ash bricks are made by applying compressive load on the mold. In this research, the effect of brick forming load on the crushing load, water absorption and unit volume weight were studied. For this purpose bricks were prepared for different fly-ash (50\% to $65 \%$ at $5 \%$ increments), gypsum (12\% to $3 \%$ at $3 \%$ decrements), sand (28\% to $22 \%$ at $2 \%$ decrements) and $10 \%$ cement. All ingredients were thoroughly mixed and then poured them to a mold of $9.5 \mathrm{~cm} \times 4.5 \mathrm{~cm} \times 2.75 \mathrm{~cm}$. Bricks were made by different forming load and mechanical properties were noted. This research suggested that it was possible to make good quality bricks using fly-ash, gypsum, sand and cement.
\end{abstract}

Keywords: Fly-ash; Gypsum; Sand; Cement; Brick forming load; Mechanical properties

Abbreviations: IS: Indian Standard

\section{Introduction}

Fly-ash is a predominantly inorganic residue obtained from the flue gases of furnaces at pulverized coal power plants. Fly-ash is

produced in a large scale in all over the world. Production of fly-ash in different countries [1] is shown in Figure 1.

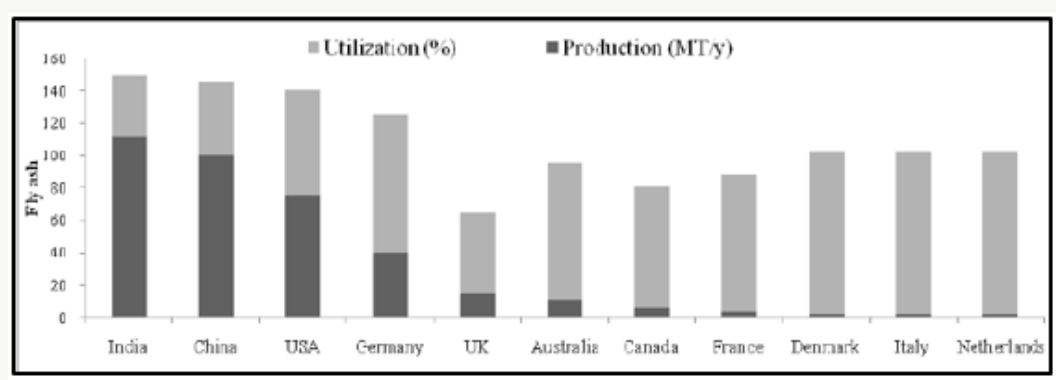

Figure 1: Fly ash production (Mg per year) and utilization (\%) in different countries.

Now it has become a concern to dispose it in a right manner. For this many researchers have tried to found out the way to use them. Fly-ash is now used in different sectors like brick making, agriculture, concrete production, embankments, road pavement, mineral filler in asphaltic concrete, mine reclamation etc. Recent review such as [2,3] presented the possible applications of fly-ash. Fly-ash is now used in agriculture to increase the land properties
[4]. Fly-ash has cementious properties. Thus, it has been used in making concrete [5]. Now fly-ash is disposed in the form of bricks. These bricks are made commercially in many countries like United Kingdom, Germany and India. Many solidifying agents are used in production of fly-ash bricks like lime [6], slag [7,8], dextrin [9] and gypsum $[10,11]$. Several numbers of patents on the use of fly-ash-lime mixures to make unfired bricks [12-15]. Gypsum is 
an important by-product of fertilizer industry and causes serious environmental problem [16]. The strength of fly ash-lime-gypsum (FaL-G) bricks and hollow blocks increased at a faster rate in initial days of curing and subsequently at a relatively lower rate. It was observed that the hot water curing leads to a greater degree of hardening and higher strength. Water absorption increases with increased fly ash content and it decreases with an increase in the density of FaL-G bricks and hollow blocks [17]. The strength of concrete increased with increasing amount of fly ash up to an optimum value and decreased with further addition of fly ash. The optimum value of fly ash for the test groups is about $40 \%$ of cement. Fly ash/cement ratio is an important factor determining the efficiency of fly ash [18]. The phenomenon of bond development between the fly ash-lime-gypsum (FaL-G) brick and the mortar. The morphological and microstructure studies of the brick-mortar interfaces clearly proved the chemical bond formation at the FaL-G brick-mortar interface [19]. The effect of incorporating various additives (i.e. cured resin, pulverized stone, pulverized plaster, and glass fibers) and two drying method (air and microwave) on compressive strength of gypsum products. Microwave drying for 5 minutes could fasten the drying time and permit early manipulation of plaster and stone models [20]. The addition of fly ash enhanced the quality of the brick, although for restoration purposes if too much fly ash (P10 wt.\%) is added, this can spoil the aesthetic appearance of the buildings being restored, due to excessive color differences [21]. The replacement of raw materials of clay by fly ash to make fired bricks is an effectively measure of saving land and decreasing pollution. The sintering temperature of bricks with high replacing ratio of clay by fly ash was about 1050C, which was 50-100C higher than that of fired clay bricks. The fired bricks were of high compressive strength, no cracking, low water absorption, high fastness to efflorescence, no frost and high resistance to frost-melting [22]. A technique for producing concrete bricks and paving blocks using C\&D wastes as recycled aggregates. The replacement of coarse and fine natural aggregates by recycled aggregates at the levels of $25 \%$ and $50 \%$ had little effect on the compressive strength of the bricks and blocks, but higher levels of replacement reduced the compressive strength [23]. The investigation of industrial wastes produced by phosphoric acid plants and boron concentrators was used in light brick production. The environmental need to utilize wastes that would be hazardous otherwise. The economy of possible use of these wastes is also of importance since the disposal of the wastes [24]. Fly-ash-gypsum bricks are used as a lightweight, heavy strength and low cost bricks. Reaction of gypsum are taken place in the presence of water. By the presence of water it forms crystalline material which is not strong enough to bear a good compressive strength but uses as a finishing materials. In the past fly-ash was released to environment. Fly ash is used as pozzolan to produce cement. Fly-ash with gypsum is made a tough material having good finishing.

\section{Experimental Programme}

\section{Materials used}

Fly-ash: Fly ash used in this research was collected from Noapara, Jessore which is imported from India. Specific gravity of fly-ash was 2.10. The chemical compositions of fly ash in India [25] are indicated in Table 1.

Table 1: Chemical composition of fly ash in India.

\begin{tabular}{|c|c|}
\hline Mineral & Fly-ash \\
\hline $\mathrm{SiO}_{2}$ & $38-63$ \\
\hline $\mathrm{Al}_{2} \mathrm{O}_{3}$ & $27-44$ \\
\hline $\mathrm{Fe}_{2} \mathrm{O}_{3}$ & $3.3-6.4$ \\
\hline $\mathrm{CaO}$ & $0.2-8$ \\
\hline $\mathrm{MgO}$ & $0.01-0.5$ \\
\hline $\mathrm{LOI}$ & $0.2-3.4$ \\
\hline $\mathrm{SO}_{3}$ & ------ \\
\hline $\mathrm{Na}_{2} \mathrm{O}$ & $-\cdots----$ \\
\hline
\end{tabular}

Gypsum: Chemically known as "Calcium sulphate hydrate". This material is non-toxic and don't create any harmful effect on the human body, environment, plant lifes and animals. Gypsum used in this research was collected from Noapara, Jessore. Specific gravity of gypsum was 2.34. The chemical compositions of natural gypsum [10] is indicated in Table 2.

Table 2: Chemical composition of natural gypsum.

\begin{tabular}{|c|c|}
\hline Mineral & Gypsum \\
\hline $\mathrm{SO}_{3}$ & 36.2 \\
\hline $\mathrm{CaO}$ & 30.1 \\
\hline $\mathrm{MgO}$ & 3.66 \\
\hline $\mathrm{SiO}_{2}$ & 3 \\
\hline $\mathrm{Al}_{2} \mathrm{O}_{3}$ & 0.85 \\
\hline $\mathrm{Fe}_{2} \mathrm{O}_{3}$ & 0.25 \\
\hline $\mathrm{TiO}_{2}$ & 0.04 \\
\hline $\mathrm{P}_{2} \mathrm{O}_{5}$ & 0.01 \\
\hline $\mathrm{Mn}_{3} \mathrm{O}_{4}$ & ------- \\
\hline $\mathrm{Na}_{2} \mathrm{O}$ & -------- \\
\hline $\mathrm{K}_{2} \mathrm{O}$ & ------- \\
\hline $\mathrm{LOI}^{\mathrm{a}}$ & 24.6 \\
\hline $\mathrm{LOI}^{\mathrm{b}}$ & --------- \\
\hline
\end{tabular}

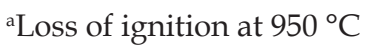

${ }^{b}$ Loss of ignition at $550{ }^{\circ} \mathrm{C}$

Sand: Locally available sand were used in this study. The specific gravity of sand was 2.78 and fineness modulus was 2.34 .

Cement: Cement is a binder, a substance used for construction that sets, hardens and adheres to other materials, binding them together. Ordinary Portland Cement was used in this study. The physical properties used are given in Table 3. 
Table 3: Physical properties of ordinary Portland cement.

\begin{tabular}{|c|c|c|}
\hline No & Characteristics & Value Obtained Experimentally \\
\hline 1 & Specific gravity & 3.14 \\
\hline \multirow{2}{*}{2} & Setting time(minutes) & \\
\cline { 2 - 3 } & Initial & 75 \\
\cline { 2 - 3 } & Final & 610 \\
\hline
\end{tabular}

Proportion and mixing of raw materials: Different proportion are used to cast fly-ash bricks. Materials are used as a percentage of the volume of the mold. Percentage of materials required for fly-ash bricks and brick no. for each proportion in different curing process and curing period Table 4 .

Table 4: Percentage of materials required for fly-ash bricks and brick no. for each proportion in different curing process and curing period.

\begin{tabular}{|c|c|c|c|c|c|c|}
\hline Proportion no. & & & A & B & C & D \\
\hline \multirow{3}{*}{ Brick No. } & \multirow{2}{*}{$\begin{array}{l}\text { For compressive } \\
\text { strength }\end{array}$} & Air curing & $\mathrm{A} 1, \mathrm{~A} 2, \mathrm{~A} 3$ & B1,B2,B3 & $\mathrm{C} 1, \mathrm{C} 2, \mathrm{C} 3$ & D1,D2,D3 \\
\hline & & Water curing & $\mathrm{A} 4, \mathrm{~A} 5, \mathrm{~A} 6$ & $\mathrm{~B} 4, \mathrm{~B} 5, \mathrm{~B} 6$ & $\mathrm{C} 4, \mathrm{C} 5, \mathrm{C} 6$ & D4,D5,D6 \\
\hline & \multicolumn{2}{|c|}{ Unit weight \& water absorption } & $\mathrm{A} 7, \mathrm{~A} 8, \mathrm{~A} 9$ & $\mathrm{~B} 7, \mathrm{~B} 8, \mathrm{~B} 9$ & $\mathrm{C} 7, \mathrm{C} 8, \mathrm{C} 9$ & D7,D8,D9 \\
\hline \multicolumn{3}{|c|}{ Fly-ash (\%) } & 50 & 55 & 60 & 65 \\
\hline \multicolumn{3}{|c|}{ Gypsum (\%) } & 12 & 9 & 6 & 3 \\
\hline \multicolumn{3}{|c|}{ Sand (\%) } & 28 & 26 & 24 & 22 \\
\hline \multicolumn{3}{|c|}{ Cement (\%) } & 10 & 10 & 10 & 10 \\
\hline
\end{tabular}

The amount of ingredients was weighted then mixed thoroughly in a dry state. When the colour of the mixed was seemed to uniform then water was added. After addition of the required quantity of water the mixture was thoroughly mixed in a pan. The water content used in this study was $80 \mathrm{ml}$. The mixture was again thoroughly mixed until the mixture attained a uniform consistency.

\section{Preparation of mortar blocks}

A brick mold of size $9.5 \mathrm{~cm} \times 4.5 \mathrm{~cm} \times 2.75 \mathrm{~cm}$ was used in this study. Then the mortar was placed on the mold and compacted using digitec concrete compression machine. The load was applied with average time of 15 seconds to 20 seconds. Then the excess mortar was hand finished. Nine specimens were prepared for each proportion. After that the brick forming load from the screen of the digitec concrete compression machine was recorded.

Curing of brick sample: The brick sample was taken out from the mold after 10 minutes. After removal from the molds, the brick samples were kept for air drying for 2 days. After sufficient strength was gained some of these bricks were transferred to water for 14 days and others were kept in air.

Method of testing: Poping out from the water bowl after 14 days curing, bricks were tested for compressive strength using digitec concrete compression machine. Compressive strength and water absorption test were conducted by following IS:3495 [26] and unit volume weight was conducted using literature.

\section{Results and Discussion}

\section{Effect of brick forming load on crushing load}

Air curing: Table 5 gives the information of forming and crushing load on water curing fly-ash bricks while Figure 2 presents the graphical representation of table 5. In Figure 2, crushing load is experienced upward in the first and gradually decreasing to the last. On the other hand forming load is gradually upward. Brick No. A3 gives the highest crushing value from all the available bricks which is marked in the Table 5 while C1 shows lowest crushing value.

Table 5: Crushing Load $(\mathrm{kN})$ for air curing fly-ash bricks.

\begin{tabular}{|c|c|c|}
\hline Brick No & Forming Load (kN) & Crushing Load (kN) \\
\hline A1 & 33 & 66 \\
\hline A2 & 36 & 70 \\
\hline A3 & 38 & 76 \\
\hline B1 & 33 & 51 \\
\hline B2 & 36 & 52 \\
\hline B3 & 38 & 54 \\
\hline C1 & 33 & 41.25 \\
\hline C2 & 35 & 44.23 \\
\hline C3 & 40 & 53.15 \\
\hline D1 & 40.8 & 46.58 \\
\hline D2 & 43.2 & 48.28 \\
\hline D3 & 52.8 & 52.78 \\
\hline
\end{tabular}

Water curing: Table 6 illustrates the forming load as well as crushing of fly-ash bricks of water curing of 12 bricks while Figure 3 represent the graphical demonstration of Table 6. Figure 3 shows a variety of deflections in crushing load of fly-ash bricks. Brick No. A3 gives the maximum crushing value i.e., $62.5 \mathrm{kN}$ and D5 shows the lowest crushing value of about $31.28 \mathrm{kN}$ shown in Table 6. Both values are highlighted to visualize easily with graphical representation. 


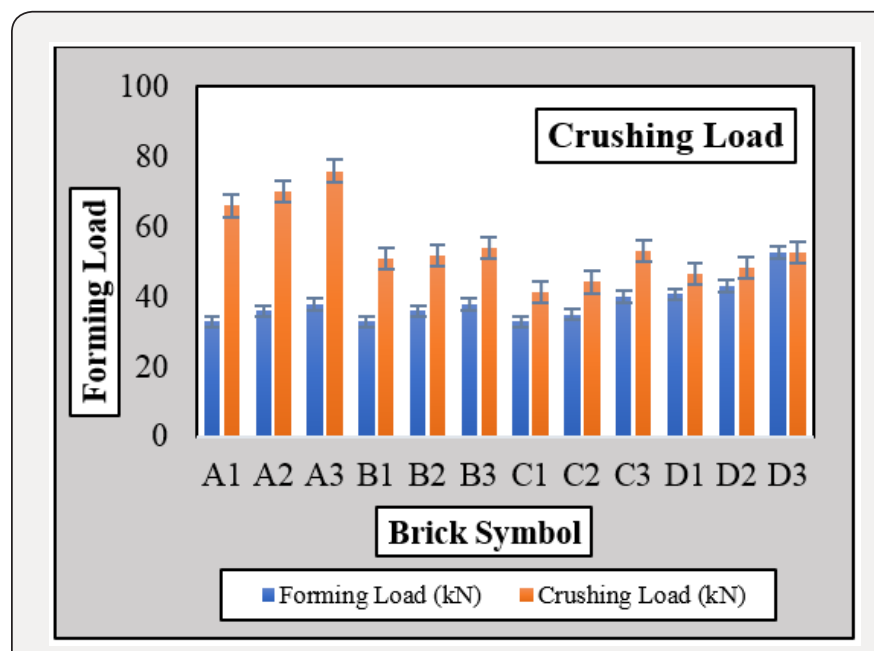

Figure 2: Variation of forming and crushing load for air curing fly ash bricks.

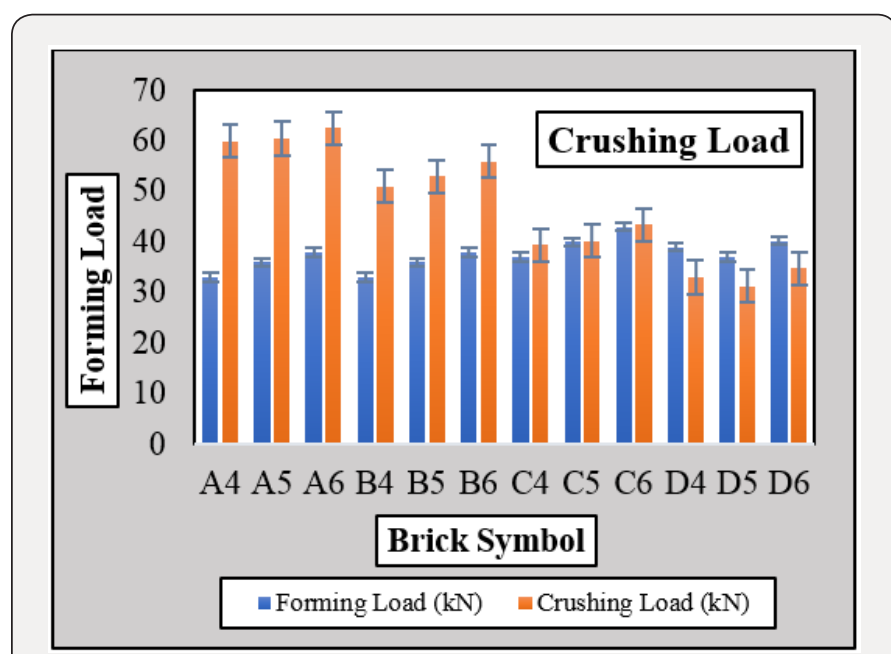

Figure 3: Variation of forming load and crushing load for water curing fly-ash bricks.

Table 6: Crushing Load ( $\mathrm{kN})$ for water curing fly-ash bricks.

\begin{tabular}{|c|c|c|}
\hline Brick No & Forming Load $(\mathrm{kN})$ & Crushing Load $(\mathrm{kN})$ \\
\hline A4 & 33 & 60 \\
\hline A5 & 36 & 60.5 \\
\hline A6 & 38 & 62.5 \\
\hline B4 & 33 & 51 \\
\hline B5 & 36 & 53 \\
\hline B6 & 38 & 56 \\
\hline C4 & 37 & 39.36 \\
\hline C5 & 40 & 40.26 \\
\hline C6 & 43 & 43.45 \\
\hline D4 & 39 & 33.06 \\
\hline D5 & 37 & 31.28 \\
\hline D6 & 40.2 & 34.8 \\
\hline
\end{tabular}

Table 7: Forming load on water absorption of fly-ash bricks.

\begin{tabular}{|c|c|c|}
\hline Brick No & Forming Load (kN) & Water Absorption (\%) \\
\hline A7 & 33 & 21 \\
\hline A8 & 36 & 20 \\
\hline A9 & 38 & 19.8 \\
\hline B7 & 33 & 20.56 \\
\hline B8 & 36 & 20.1 \\
\hline B9 & 38 & 19.56 \\
\hline C7 & 35 & 22.2 \\
\hline C8 & 38 & 20 \\
\hline C9 & 37 & 21.34 \\
\hline D7 & 32 & 22.2 \\
\hline D8 & 35.5 & 21.83 \\
\hline D9 & 39 & 22 \\
\hline
\end{tabular}

Effect of brick forming load on water absorption: Table 7 depicts the variation of water absorption in accordance with the brick forming load in a tabular format and with the help of these data a graph was plotted to easy visualization (Figure 4). Marked B9 and C7 shows lowest and highest water absorption respectively. The bar diagram shows almost same variations which is indicated in the Figure 4.

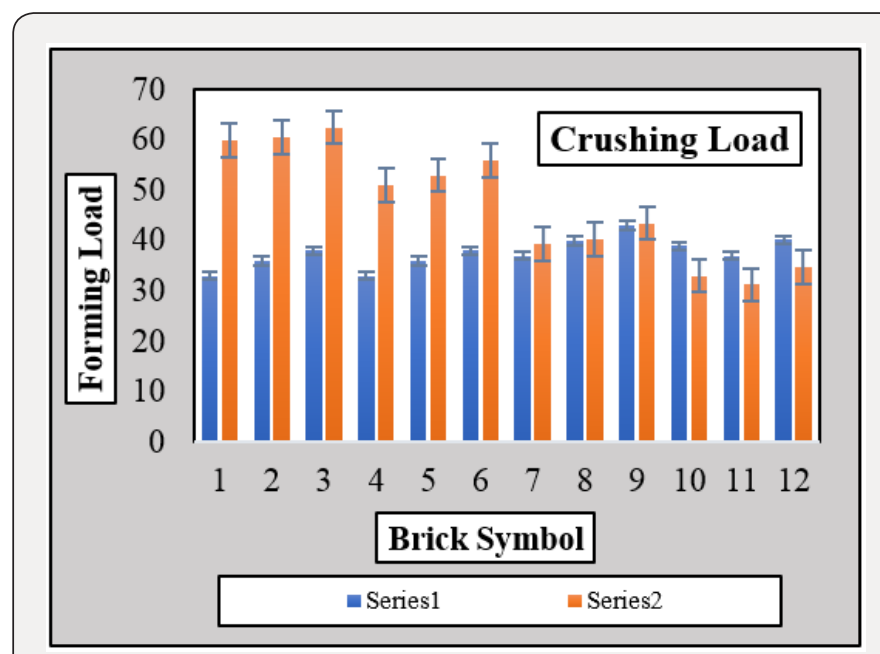

Figure 4: Variation of water absorption with respect to forming load of fly-ash bricks.

Effect of brick forming load on unit volume weight: Experimental data on conducting research on fly-ash bricks have been illustrated in a table format in Table 8 and a bar graph (Figure 5) was used to show the variation unit volume weight with the brick forming load. Though forming loads show a variations but unit volume weight seems like a plain straight. 
Table 8: Forming load on unit volume weight of fly-ash bricks.

\begin{tabular}{|c|c|c|}
\hline Brick No & Forming Load (kN) & Unit Weight \\
\hline A7 & 33 & 1.54 \\
\hline A8 & 36 & 1.55 \\
\hline A9 & 38 & 1.56 \\
\hline B7 & 33 & 1.49 \\
\hline B8 & 36 & 1.5 \\
\hline B9 & 38 & 1.51 \\
\hline C7 & 35 & 1.46 \\
\hline C8 & 38 & 1.49 \\
\hline C9 & 37 & 1.48 \\
\hline D7 & 32 & 1.45 \\
\hline D8 & 35.5 & 1.46 \\
\hline D9 & 39 & 1.47 \\
\hline
\end{tabular}

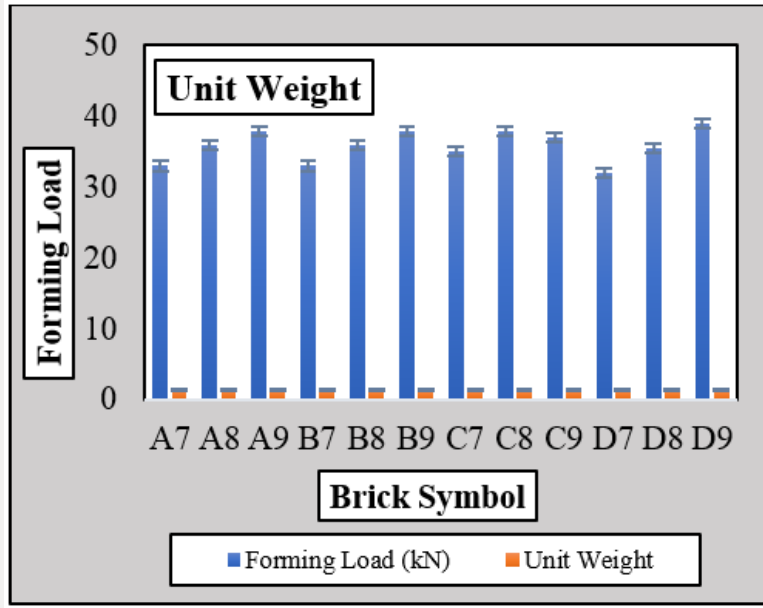

Figure 5: Variation of unit volume weight with respect to brick forming load of fly-ash bricks.

\section{Conclusion}

Usually, FA obtained high strength at the initial stage of the formation of fly ash bricks while FA need long term hydration for the FA. In this study, it is found that crushing load for the water curing is higher at the brick no. of A6 shown in the Table 6. For considering the air curing into account, and displayed maximum crushing load for the brick A3 shown in Table 5 and by bar diagram in Figure 2. The maximum crushing load for air and water curing for fly-ash bricks were 76 and $62.5 \mathrm{kN}$ respectively while minimum crushing load were 41.25 and $31.28 \mathrm{kN}$ for air and water curing respectively. By performing the comparison between air and water curing, an interesting outcome is found that crushing load for air is greater than the crushing load for water curing. It may be happened due to initial hydration effect of fly ash.

By taking water absorption, it is shown in Table 7 along with the Figure 4 that B9 and C7 gives the maximum and minimum water absorption respectively. Looking to the other bricks demonstrates almost same fluctuations of water absorption. Almost same results were found also in the unit weight of the fly ash bricks in which the results (Figure 5) displays the same height at the forming load.

By doing the study, it may be concluded that proportion for brick " $\mathrm{A}$ " is quite good rather than other bricks. More research should be conducted on fly ash bricks to attain more accurate results and relationship.

\section{References}

1. https://www.researchgate.net/figure/Fly-ash-production-Mg-peryear-and utiliz-ation-in-different-countries_fig1_255947847.

2. Yao ZT, Ji XS, Sarker PK, Tank JH, Ge LQ, et al. (2015) A comprehensive review on the applications of coal fly ash. Earth Sci Review 141: 105121.

3. Ahmaruzzaman M (2010) A review on the utilization of fly ash. Prog Energy Combust Sci 36(3): 327-363.

4. Manisha B, Manish P, Bhadoria PBS, Mahapatra SC (2009) Potential flyash utilization in agriculture: A global review. Prog Natural Sci 19(10): 1173-1186.

5. Islam MM, Islam MS (2013) Strength and durability characteristics of concrete made with $\mathrm{fl} y$-ash blended cement. Australian Journal of Structural Engineering 14(3): 303-319.

6. Chindaprasirt P, Pimraksa K (2008) A study of fly ash-lime granule unfired brick. Powder Tech 182(1): 33-41.

7. Freidin K, Erell E (1995) Bricks made of coal fly-ash and slag, cured in the open air. Cement Concrete Com 17(4): 289-300.

8. Zhiwei Z, Jueshi Q, Chao Y, Changhua H (2012) Use of circulating fluidized bed combustion fly ash and slag in autoclaved brick. Cons Build Mat 35: 109-116.

9. Sandra G Lingbawan (2009) Thermal properties of Fly Ash Bricks. ADFA Journal Of Undergraduate Engineering Research 2(2).

10. Antomio T, Milena M, Daniela C, Gian LV, Fabio M (2013) Flue gas desulfurization gypsum and coal fly ash as basic components of prefabricated building materials. Waste Manage 33(3): 628-633.

11. Sunil K (2002) A perspective study on fly-ash-lime-gypsum bricks and hollow blocks for low cost housing development. Cons Build Mat 16: 519-525.

12. Huailin Z, Wenching W (1996) China Pat. No. CN 95-10846 19950714.

13. Shenxian Y (1999) China Pat. No. CN 97-11873 19970921.

14. Cooke AJ, Prakopovich SA (1986) Compacted FA-lime building products cured at low temperature, 12th Proc-Aust Ceram Conf, Auckland, New Zealand, pp. 112-120.

15. Kumar S (2000) Fly ash-lime-phosphogypsum hollow blocks for walls and partition. Build Environ 38(2): 291-295.

16. Singh M, Garg M (1997) Durability of cementitious binder derived from industrial wastes. Mater Struct 30(10): 607-612.

17. Sunil K (2002) A perspective study on fly ash-lime-gypsum bricks and hollow blocks for low cost housing development. Cons Build Mate 16(8): 519-525.

18. Oner A, Akyuz S, Yildiz R (2005) An experimental study om strength development of concrete containing fly ash and optimum usage of fly ash in concrete. Cem Con Res 35(6): 1165-1171.

19. Gourav K, Venkatarama RBB (2018) Bond development in burnt clay and fly ash-lime-gypsum brick masonry. J Mater Civ Eng 30(9): 04018202. 
20. Kati FA, Yassin IN, Razak WA (2017) Effect of adding some additives and drying method on compressive strength of gypsum products. Ti J Den Sci 5: 25-32.

21. Giuseppe C, Eduardo S (2009) Fly ash addition in clayey materials to improve the quality of solid bricks. Cons Build Mater 23(2): 1178-1184.

22. Lingling Z, Wei G, Tao W, Nanru Y (2005) Study on fired bricks with replacing clay by fly ash in high volume ratio. Cons Build Mater 19(3): 243-247.

23. Poon CS, Kou SC, Lam L (2002) Use of recycled aggregates in molded concrete bricks and blocks. Cons Build Mater 16(5): 281-289.
24. Abah Y, Yurdusev MA, Zeybek MS, Kumanhogia AA (2007) Using photogypsume and boron concentrator wastes in light brick production. Cons Build Mater 21(1): 52-56.

25. Pandian NS (2004) Fly ash characterization with reference to geotechnical applications. J Indian Inst Sci 84: 189-216.

26. (1992) IS: 3495, Methods of tests of burnt clay building bricks, Bureau of Indian Standards, New Delhi, India.

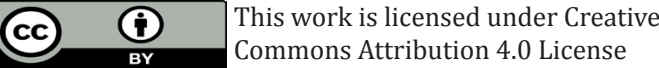

To Submit Your Article Click Here:

Submit Article

DOI: 10.32474/TCEIA.2018.03.000157

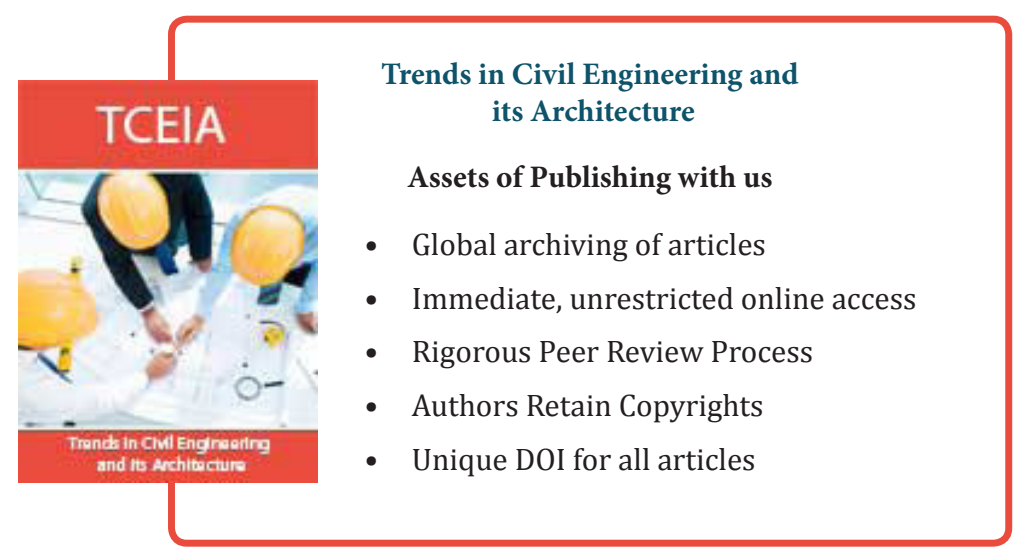

